\title{
空洞断面を有するセメント系押出成形部材の曲げ性状に関する実験的研究 AN EXPERIMENTAL STUDY ON FLEXURAL BEHAVIORS OF EXTRUDED
CEMENTITIOUS COMPONENTS WITH HOLLOW
}

\author{
眞方山 美穂*1, 馬場明生 ${ }^{* 2}$, 守 明子*3, 堀口昌 利*4, 渡 部 嗣 道*5 \\ Miho MAKATAYAMA, Akio BABA, Akiko MORI, \\ Masatoshi HORIGUCHI and Tsugumichi WATANABE
}

It is able to produce cementitious components with various sectional geometries, hollow, ribbed and so on, by extrusion moulding. This paper deals with a comprehensive experiment on the effect of hollow ratio in the area of extruded cementitious components on flexural strength by using chrysotile and hydrophilically treated polypropylene fiber. The following items are clarified.

1) First cracked flexural strength can be determined on the basis of cement water ratio theory or cement void ratio one regardless of hollow ratio.

2) Ductility after cracking is confirmed for hollow type composite using hydrophylically treated polypropylene fiber.

Keywords : cementitious components, extrusion moulding, hollow type components, first cracked flexural strength, ductility, equivalent flexural strength セメント系材料、押出成形、空洞断面部材、ひび割れ発生曲げ強度、勒性、換算曲げ強度

\section{1.はじめに}

現在、建設廃棄物の排出総量を低減するための取り組みが盛んに 進められており、鉄筋コンクリートエ事における打込み型枠構工法 は、その一つと捉えることができる。打込み型枠部材に用いる材料 には、ガラス瀻維や合成樹脂系混和材による高強度セメント系部材 をはじめ、フラットデッキなどの鋼板等、様々な種類のものがある が、セメント系押出成形部材は、曲げ比強度が大きいため型枠部材 の厚さを小さくすることが可能であり、またコンクリ一トとの一体 性確保の点で有利な满型やリブ付き断面形状とすることができるの で、打込み型枠部材として適した材料である。

躯体の外皮を構成する打込み型枠部材にとって、曲げ強度は重要 な性能であり、運般・般入時のみならずコンクリート打設時の施工 荷重に対抗する安全性ならびに地震動時の構造安全性を考えると、 面外曲げ強度が大きいことが望まれる。また、現場での施工のしゃ すさや大型の揚重機が使えない狭㿽な敷地での施工を考えると、部 材の軽量化が必要となってくる。

部材の軽量化を達成する方法としては、素材の曲げ強度を向上さ せ、断面を空洞化する方法がある。断面の空洞化による部材の軽量 化については、守らの研究 ${ }^{1)}$ の中で理論的な検討結果が報告されて いる。その一つに、外部形状を同一として部材の最大抵抗曲げモー
メント一定という条件の下で素材強度を 2 倍に改善した場合、部材 の嵩密度は約 25\%と飛躍的に小さくできるという試算結果がある。 これが実際の製造においても成り立つならば、部材の軽量化にあた って断面を空洞化することは非常に有効である。セメント系材料を 対象とした場合、このような断面の空洞化は、押出成形法において のみ可能な技術であり、材料調合をエ夫して素材を高強度化し、空 洞化などの適切な断面設計を行うことにより、高い曲げ比強度を実 現することも可能と考えられる。

ここでは、材料条件、押出成形機の機械条件および試験条件等を 変化させて得られた、空洞断面を有するセメント系押出成形部材の 曲げ強度および勒性に関する包括的な一実験研究結果について報告 する。ここで得られた成果は、部材断面を変化させた場合の強度性 状を定量的に検討する際の基礎資料となるものである。

\section{2. 既往の研究}

押出成形法は、プラスチック材料や金属材料の加工において広く 適用されている成形法であるので、これらの材料を対象とした製造 特性に関する研究は数多く報告されている。一方、セメント系材料 を対象にした押出成形に関する研究デー夕は筆者らの知る限りにお いて極めて少なく、製造特性に関する研究 2) 7)、中実断面部材の

\footnotetext{
*1 独立行政法人建築研究所第 4 研究部 主任研究員 - 工修

*2 山口大学工学部感性デザイン工学科教授・工博

*3 名古屋工業大学工学部社会開発工学科 教授 ·博士 (工学)

*4 昭和電工建材侏石岡工場生産 ·技術部 副主席

*5 山口大学工学部感性デザイン工学科 助手・工修
}

Senior Research Engineer, Building Research Institute, M. Eng.

Prof., Dept. of Perceptual Sciences and Design Engineering, Faculty of Engineering, Yamaguchi Univ., Dr. Eng.

Prof., Dept. of Architecture and Civil Engineering, Faculty of Engineering Nagoya Institute of Technology, Dr. Eng.

Senior Research Engineer, Showa Denko Kenzai K.K

Assist. Prof., Dept. of Perceptual Sciences and Design Engineering, Faculty of Engineering, Yamaguchi Univ., M. Eng. 
曲げ性能に関する研究8)、91、ポリプロピレン短織維を用いた部材

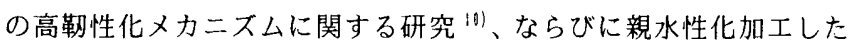
ポリプロピレン繊維により勒性を付与し、さらに部材厚さの影響に ついて検討した研究 ${ }^{11}$ などがある。しかしながら、部材断面の空 洞化に関しては、守らによる理論的な検討 ${ }^{12)}$ が報告されているに すぎず、空洞断面部材の実験的検討に関するデー夕は、筆者らが知 る限りにおいて公表されていない。

部材断面の空洞化について理論的に整理されたデータが一般的に なっていないこともあり、実機プラントにおいて断面形状を変更す るに際しては、製品の形状のみならず、部材の力学的性能とも密接 に関係している材料調合もあわせて試行錯誤的に検討し、所要の性 能を得ているのが現状である。

\section{3. 実験方法}

\section{1 モルタル試料}

セメントには普通ポルトランドセメント（M社製（JIS R 5210)） を、細骨材には豊浦硅砂を用いた。セメント系材料の押出成形にお いては製造時の可塑性を確保するため、通常のモルタルを構成する 材料の他に増粘剂および繊維質添加材が必要である。ここでは、增 粘剤としてメチルセルロース（S 社製 90SH-4000）を、緎維質添加材 としてセメント系材料の押出成形で標準的物質として筆者らが用い てきたクリソタイル 6D（JIS M 8602)ならびに押出成形において䩗 性付与が確認された織維表面を親水性化加エしたポリプロピレン緎 維（SD 社製、以下、親水性化 PP と記す。）を用いた。緎維質添加材 の物性を Table 1 に、モルタル調合をTable 2 に示す。モルタルの 水量比*は、クリソタイルを添加したモルタルについては 0.13,0.15, $0.20,0.25$ の 4 水準とし、親水性化 PP を添加したモルタルについ ては $0.13,0.15,0.175$ の3水染とした。

*ここで、水量比とは、使用材料のうちセメント、細骨材、水の総質量に対 する水の質量比である。

\section{2 押出成形実験}

\subsection{1 部村断面形状}

Table 3 に部材の断面形状を示す。これまで筆者らはセメント系 押出成形部材の曲げ性能に関する実験においては、部材幅 $60 \mathrm{~mm}$ を基 本として部材厚さを $12 \mathrm{~mm} 、 15 \mathrm{~mm} 、 25 \mathrm{~mm}$ とした中実断面の部材を成形 し、試験を行ってきた。ここでは、部材断面の空洞率が曲げ強度に
及ぼす影響を明らかにするため、部材厚さを $25 \mathrm{~mm}$ 一定とし、部材幅 $60 \mathrm{~mm} 、 100 \mathrm{~mm}$ で空洞率を $0 \% 、 33.8 \%$ および $45.0 \%$ とした。部材断面 のシェルやウェブの厚さは、空洞部の形状が正方形とすることによ り決めた。

\subsection{2 押出成形工程と成形機械}

押出成形の工程をFigure 1 に示す。各材料を強制ミキサーで混合 した後、混練機（ニーダ）で混練し、Table 4 に示す真空押出成形 機を用いて所要の断面形状を有する部材を押し出した。なお、ここ では、 $60 \mathrm{~mm}$ 幅の部材の成形にはバレル径 $50 \mathrm{~mm}$ の押出成形機を使用 し、部材幅 $100 \mathrm{~mm}$ の部材の成形にはバレル径 $75 \mathrm{~mm}$ のものを使用した。 押出成形機には、混練された材料を給材する際にその量を調整す る目的で、押出成形機のミルと真空脱気室の間に仕切りとして、「目 皿」と呼ばれる丸い孔が空いた部品が取り付けられている。混練さ れた材料の水量比が小さく、硬いものを押し出そうとした場合に、 この目皿の孔の径によっては成形が困難になることがある。今回の 部材成形においては、目皿は予め成形機にセットされていたものを 使用することとし、部材幅 $60 \mathrm{~mm}$ については孔の大きな目皿を、部材 幅 $100 \mathrm{~mm}$ については孔の小さい目四を標準として赛験を行った。な お、モルタル試料の水量比が小さい場合には、前述したように成形 が困難となることも予想されるため、その時には目血を交換できる よう準備をして、成形に取りかかることとした。

\subsection{3 モルタル調合}

本研究で押し出した曲げ強度測定用の供試体は、部材幅により瀻 維質添加材、空洞率および水量比の組み合わせが異なる。幅 $60 \mathrm{~mm}$ の部材のモルタル調合を Table 5(a)示す。緎維質添加材としてクリ ソタイルを用いた部材は、水量比 $0.13 、 0.15 、 0.20$ および 0.25 の 4 水準について、また親水性化 PP を用いた部材については水量比 0.15 の 1 水準について各空洞率の部材を成形した。幅 $100 \mathrm{~mm}$ の部材 のモルタル調合を同表(b)に示す。クリソタイルを用いた部材は幅 $60 \mathrm{~mm}$ の部材と同じく水量比 0.13 から 0.25 の 4 水準について各空洞 率の部材を成形した。親水性化PPについては、水量比 0.13 の空洞 率 $33.8 \%$ の部材を除いた、水量比 $0.13 、 0.15$ および 0.175 の 3 水準 について各空洞率の部枋を成形した。成形された供試体は、 $20^{\circ} \mathrm{C} の$ 室内で 1 日封か九養生した後、 $20^{\circ} \mathrm{C}$ の水中で 28 日の材路まで養生し、 曲げ強度测定用供試体とした。

Table 1 Properties of fiber used in the experiments

\begin{tabular}{l|c|c|c|c|c|c}
\hline Kind of fiber & $\begin{array}{c}\text { Density } \\
\left(\mathrm{g} / \mathrm{cm}^{3}\right)\end{array}$ & Diameter & $\begin{array}{c}\text { Aspect } \\
\text { ratio(-) }\end{array}$ & $\begin{array}{c}\text { Tensile } \\
\text { strength } \\
(\mathrm{MPa})\end{array}$ & $\begin{array}{c}\text { Young's } \\
\text { Modulus } \\
(\mathrm{GPa})\end{array}$ & $\begin{array}{c}\text { Elongation } \\
(\%)\end{array}$ \\
\hline Chrysotile & 2.74 & $7 \AA$ & - & 1863 & $70-140$ & - \\
\hline $\begin{array}{l}\text { Polypropylene } \\
\text { (Hydrophilic fiber) }\end{array}$ & 0.91 & $17-19 \mu \mathrm{m}$ & $158-176$ & 588 & 6.37 & $35-45$ \\
\hline
\end{tabular}

Table 2 Mix proportions of mortar used in the experiments

\begin{tabular}{l|c|c|c|c|c}
\hline Kind of fiber & $\begin{array}{c}\text { Sand cement } \\
\text { ratio(s/c) }\end{array}$ & $\begin{array}{c}\text { Water content } \\
\text { ratio(-) }\end{array}$ & $\begin{array}{c}\text { Water cement } \\
\text { ratio(-) }\end{array}$ & $\begin{array}{c}\text { Methylcellulose } \\
\text { content ratio(-) }\end{array}$ & $\begin{array}{c}\text { Fiber content } \\
\text { ratio(-) }\end{array}$ \\
\hline Chrysotile & 1.00 & $0.13-0.25$ & $0.299-0.667$ & 0.01 & 0.05 \\
\hline $\begin{array}{l}\text { Polypropylene } \\
\text { (Hydrophilic fiber) }\end{array}$ & 1.00 & $0.13-0.175$ & $0.299-0.424$ & 0.01 & $0.0166^{* 1}$ \\
\hline
\end{tabular}

(Note) ${ }^{*} 1$ In case of Polypropylene, fiber volume is the same of Chrysotile. 


\section{3 曲げ試験}

曲げ試験はFigure 2 に示すよ́うに単純支持、二等分点中央載荷と し、曲げスパン（L）は供試体厚さ（t）の10 倍となるように設定 した。載荷は、 $1 \mathrm{~mm} / \mathrm{min}$ の変位制御とし、荷重ならびに載荷点にお ける変位 $(\delta)$ を測定した。得られた荷重一たわみ曲線からをひび 割れ発生曲げ強度、終局曲げ強度および換算曲げ強度を算出した。 終局曲げ強度は、ひび割机発生後のいわ沛る勒性を示す部分におけ
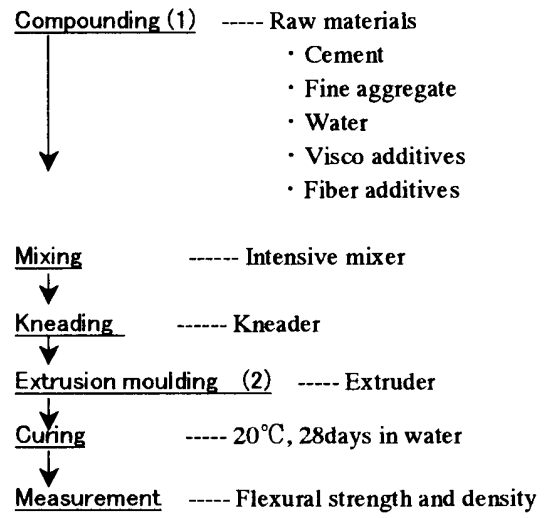

Figure 1 Flow chart for extrusion process and measuring points of some kinds of density

Table 3 Geometries of products in the experiments

\begin{tabular}{|c|c|c|c|}
\hline \multicolumn{2}{|c|}{$\begin{array}{l}\text { Geometry of products }(\mathrm{mm}) \\
\text { (Hollow ratio } \%)\end{array}$} & \multirow{2}{*}{$\begin{array}{c}\begin{array}{c}\text { Shell } \\
\text { thickness } \\
(\mathrm{mm})\end{array} \\
25 \\
\end{array}$} & \multirow{2}{*}{$\begin{array}{c}\begin{array}{c}\text { Area of geometry } \\
\text { of products }\left(\mathrm{cm}^{2}\right)\end{array} \\
15.0\end{array}$} \\
\hline & $60 \times 25$ & & \\
\hline $5 \square \square 5$ & $\begin{array}{l}60 \times 25 \\
(33.8)\end{array}$ & 6 & 9.93 \\
\hline$\sqrt{\square \square} \square$ & $\begin{array}{l}60 \times 25 \\
(45.0)\end{array}$ & 5 & 8.25 \\
\hline & $100 \times 25$ & 25 & 25.0 \\
\hline 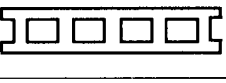 & $\begin{array}{r}100 \times 25 \\
(33.8)\end{array}$ & 6 & 16.55 \\
\hline$\square \square \square \square[$ & $\begin{array}{r}100 \times 25 \\
(45.0)\end{array}$ & 5 & 13.75 \\
\hline
\end{tabular}

Table 4 Specifications of extruder used in the experiments

\begin{tabular}{c|c|c|c|c|c}
\hline Maker & Model & $\begin{array}{c}\text { Installed } \\
\text { mortar }(\mathrm{kw})\end{array}$ & $\begin{array}{c}\text { Conveying } \\
\text { capacity }(\mathrm{l} / \mathrm{h})\end{array}$ & $\begin{array}{c}\text { Vacuum pump } \\
(\mathrm{l} / \mathrm{min})\end{array}$ & $\begin{array}{c}\text { Barrel diameter } \\
(\mathrm{mm})\end{array}$ \\
\hline Honda & DE-50 & $\begin{array}{l}0.75 \text { (Pug-mill) } \\
1.50 \text { (Barrel) }\end{array}$ & $12-25$ & 60 & 50 \\
\hline Honda & DE-75D & $\begin{array}{l}0.75 \text { (Pug-mill) } \\
1.50 \text { (Barrel) }\end{array}$ & $15-40$ & 60 & 75 \\
\hline
\end{tabular}

Table 5(a) Experimental combinations between materials and geometries of products at barrel diameter $50 \mathrm{~mm}$

\begin{tabular}{|c|c|c|c|c|}
\hline \multirow[b]{3}{*}{ Kind of Fiber } & \multirow[b]{3}{*}{$\begin{array}{l}\text { Water } \\
\text { content } \\
\text { ratio(-) }\end{array}$} & \multirow{2}{*}{\multicolumn{3}{|c|}{ Geometry of product $(\mathrm{mm})$}} \\
\hline & & & & \\
\hline & & $\begin{array}{r}60 \times 25 \\
\text { Solid }\end{array}$ & $\begin{array}{c}60 \times 25 \\
\text { Hollow } \\
(33.8 \%)\end{array}$ & $\begin{array}{c}60 \times 25 \\
\text { Hollow } \\
(45.0 \%)\end{array}$ \\
\hline Chrysotile & $\begin{array}{l}0.13 \\
0.15 \\
0.20 \\
0.25\end{array}$ & $\begin{array}{l}0 \\
0 \\
0 \\
0\end{array}$ & $\begin{array}{l}0 \\
0 \\
0 \\
0\end{array}$ & $\begin{array}{l}0 \\
0 \\
0 \\
0\end{array}$ \\
\hline $\begin{array}{l}\text { Polypropylene } \\
\text { (Hydrophilic } \\
\text { fiber) }\end{array}$ & $\begin{array}{c}0.13 \\
0.15 \\
0.175 \\
\end{array}$ & $\overline{0}$ & $\overline{0}$ & $\begin{array}{c}- \\
-\end{array}$ \\
\hline
\end{tabular}

る上に凸の荷重一たわみ曲線の極值より求めた。換算曲げ強度は、 日本コンクリート工学協会「瀻維補強コンクリートの試験方法に関 する基準」 ${ }^{13)}$ に準拠し、たわみ $(\delta)$ がスパン $(\mathrm{L})$ の $1 / 150$ となる

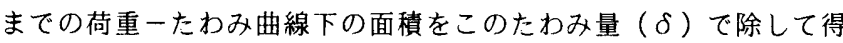
られた平均荷重から算出した。

\section{4 有効セメント水比}

筆者らのこれまでの研究 ${ }^{81 ， 91}$ により、水量比により押出成形直 後の供試体に含まれる空気量は異なっていること、また、この空気 量が曲げ強度に影響を与えていることが明らかになっている。そこ で、押出成形された部材の絰密化程度を把握するため、押出成形直 後（Figure 1 中の(2)) に試料を採取し、質量および寸法を測定し た。それらの值から押出成形直後の表乾密度を算出した。その後、 $105^{\circ} \mathrm{C}$ のアン付き乾燥機にて恒量になるまで乾燥させ、再度質量を 測定し、絶乾密度を算出した。求められた表乾密度と絶乾密度の差 から成形直後の供試体中の水量比を求めた。

一方、各モル夕ル試料の密度から混合開始時のモルタルの表乾密 度を算定し（Figure 1 中の (2))、設計密度とした。この設計密度と 先に求めた成形直後の表乾密度との差から成形直後の供試体に含ま れる空気量を算出した。

これらの方法で求められた空気量から、押出成形直後の部材の有 効セメント水比を算定し、各種曲げ強度との関係を検討した。ここ で有効セメント水比とは、Talbot のセメント空隙比説 ${ }^{14)}$ に基づい て押出成形後の供試体中に含まれる空気量を同体積の水として換算 し、これを実際に成形された供試体中に含まれる水量に加えた値で セメント量を除して算出されるものである。

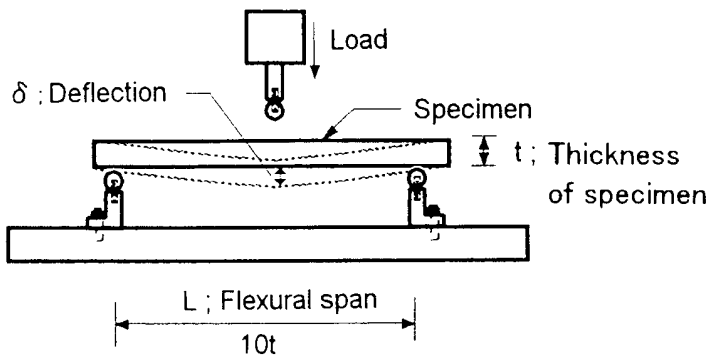

Figure 2 Flexural test apparatus
Table 5(b) Experimental combinations between materials and geometries of products at barrel diameter $75 \mathrm{~mm}$

\begin{tabular}{|c|c|c|c|c|}
\hline \multirow[b]{2}{*}{ Kind of Fiber } & \multirow[b]{2}{*}{$\begin{array}{l}\text { Water } \\
\text { content } \\
\text { ratio(-) }\end{array}$} & \multicolumn{2}{|c|}{ Geometry of product } & $(\mathrm{mm})$ \\
\hline & & $\begin{array}{c}100 \times 25 \\
\text { Solid }\end{array}$ & $\begin{array}{c}100 \times 25 \\
\text { Hollow } \\
(33.8 \%)\end{array}$ & $\begin{array}{l}100 \times 25 \\
\text { Hollow } \\
(45.0 \%)\end{array}$ \\
\hline Chrysotile & $\begin{array}{l}0.13 \\
0.15 \\
0.20 \\
0.25\end{array}$ & $\begin{array}{l}0 \\
0 \\
0 \\
0\end{array}$ & $\begin{array}{l}0 \\
0 \\
0 \\
0\end{array}$ & $\begin{array}{l}0 \\
0 \\
0 \\
0\end{array}$ \\
\hline $\begin{array}{l}\text { Polypropylene } \\
\text { (Hydrophilic } \\
\text { fiber) }\end{array}$ & $\begin{array}{c}0.13 \\
0.15 \\
0.175 \\
\end{array}$ & $\begin{array}{l}0 \\
0 \\
0\end{array}$ & $\begin{array}{l}- \\
0 \\
0\end{array}$ & $\begin{array}{l}0 \\
0 \\
0\end{array}$ \\
\hline
\end{tabular}




\section{4. 実験結果および考察}

\section{1 荷重一たわみ曲線}

Figure 3 に空洞断面を有するクリソタイルを用いた部材の荷重一 たわみ曲線の一例として、水量比 0.15 、空洞率 $0 \% 、 33.8 \% 、 45.0 \%$ の部材の結果を示す。同図より、部材幅および空洞率に関係なく全 ての部材がひび割れ発生と同時に破断し、ひび割れ発生荷重は部材 幅とは無関係に空洞率が大きいほど低下する傾向となっていること がわかる。ここには示していないが、同じ空洞率の部材と比較する と、水量比が小さいほど荷重は大きくなる傾向を示し、この関係は、 これまでに筆者らが行った中実断面部材の実験結果 ${ }^{10)}$ と同様であ った。

Figure 4 に親水性化 PP を用いた空洞断面部材の曲げ試験結果の 一例として、水量比 0.15 、空洞率 $0 \% 、 33.8 \% 、 45.0 \%$ の部材の荷重 一たわみ曲線を示す。同図より、親水性化 PP を用いると部材断面 を空洞化した部材についてもひび割れ発生の後、破断に至るまで たわみを生じており、勒性が付与されていることが確認できた。 また、ひび割れ発生荷重は、断面の空洞率が大きいほど小さくな っており、この点はクリソタイルを用いた部材と同じ結果となっ た。当然のことながら、部材幅 $100 \mathrm{~mm}$ の方が幅 $60 \mathrm{~mm}$ の部材よりも ひび割れ発生荷重は大きくなるが、幅 $60 \mathrm{~mm}$ の部材はひび割れ後に おいても荷重を保ちながら変形し続けており、部材幅が小さい方 が変形性能は優れているという結果となった。

次に空洞率別に整理した荷重ーたわみ曲線について、Figure 5 に部材幅 $60 \mathrm{~mm}$ の結果を、Figure 6 に部材幅 $100 \mathrm{~mm}$ の結果を示す。 総じて水量比が小さいほど、ひび割れ発生曲げ荷重が大きくなる傾
向を示し、また、一部の水量比については実験データが揃ってはい ないが、同じ空洞率の断面について比較すると、ひび割れ発生後の 変形能力は水量比が大きい方が優れているという結果となった。特 に、Figure 6 に示した部材幅 $100 \mathrm{~mm}$ については、水量比 0.175 のひ び割れ発生後の変形能力は他の水量比に比べて非常に大きくなった。 終局荷重については、Figure 5 に示す幅 $60 \mathrm{~mm}$ の部材は、水量比 0.15 が最も大きくなった。幅 $100 \mathrm{~mm}$ の部材については、Figure 6 に示す と书り空洞率 $0 \%$ にいてのみ水量比 0.175 の終局荷重が非常に大き くなる結果を示したが、他の空洞断面部材については水量比に関係 なく終局荷重はほぼ同じ程度となった。

\section{2 ひび割れ発生曲げ強度}

\subsection{1断面の空洞率とひひ割れ発生曲げ強度}

Figure 7 にひび割れ発生曲げ強度と空洞率との関係を示す。同図 (a)は、織維質添加材としてクリソタイルを用いた部材の部材幅 60mm の結果、また、同図(b)は部材幅 $100 \mathrm{~mm}$ の結果である。部材幅 $60 \mathrm{~mm}$ については、水量比 0.13 のみ断面を空洞化することによって、 ひび割れ発生曲げ強度の低下が認められたが、それ以外の部材は断 面に占める空洞の割合が増えてもひび割れ発生曲げ強度の低下はほ とんど見られない。部材幅 $100 \mathrm{~mm}$ については、同図(b)を見る限りで は、全体的な傾向として、部材断面を空洞化することによって、ひ び割れ発生曲げ強度は小さくなっている。しかしながら、その程度 は水量比により異なっており、水量比 0.25 の部材については空洞化 によりひび割れ発生曲げ強度が低下する割合は僅かに小さくなる程 度であるが、水量比が小さくなるとともに空洞断面部材と中実部材

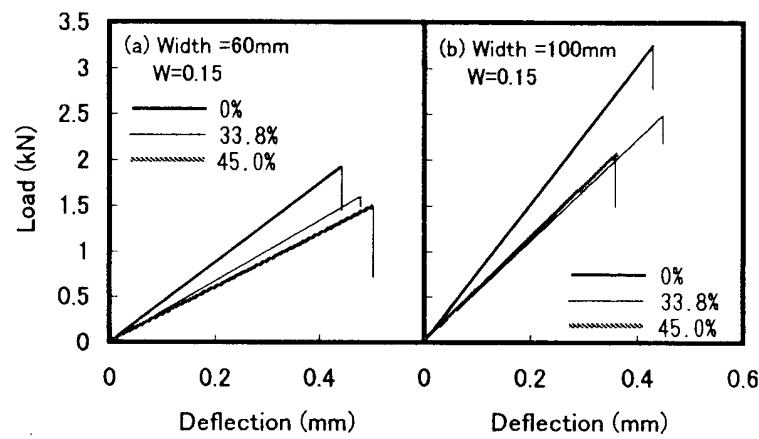

Figure 3 Flexural load-deflection relationships (Chrysotile, water content ratio $0.15,28$ days)

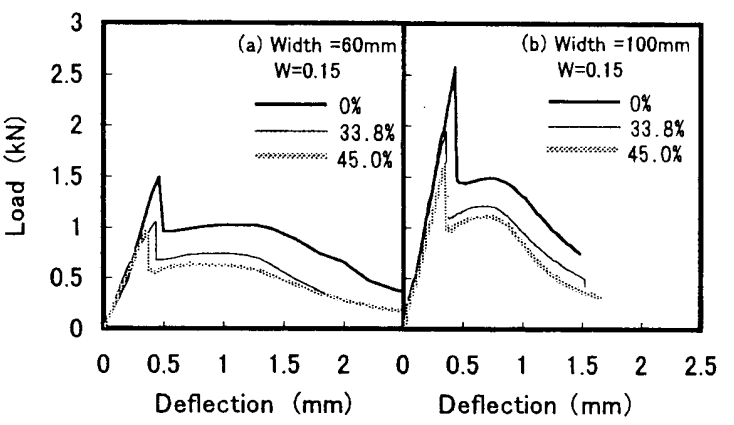

Figure 4 Flexural load - deflection relationships (Polypropylene, water content ratio $0.15,28$ days)

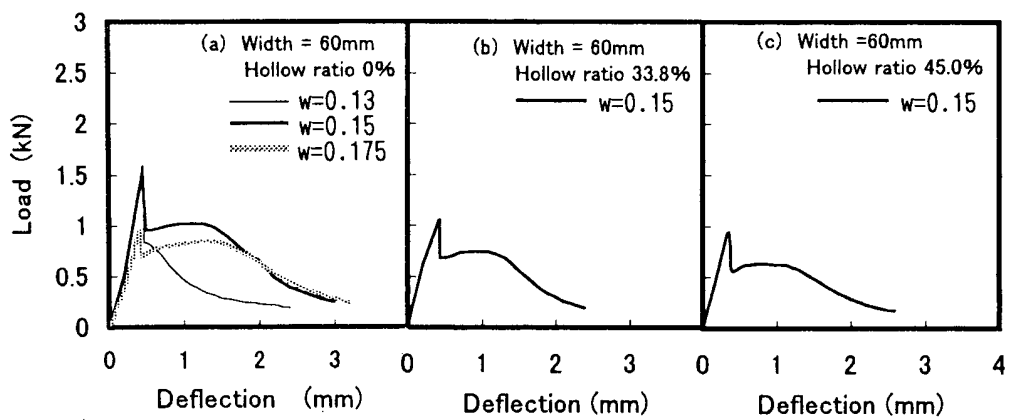

Figure 5 Flexural load-deflection relationships (Polypropylene, width 60mm, 28days)

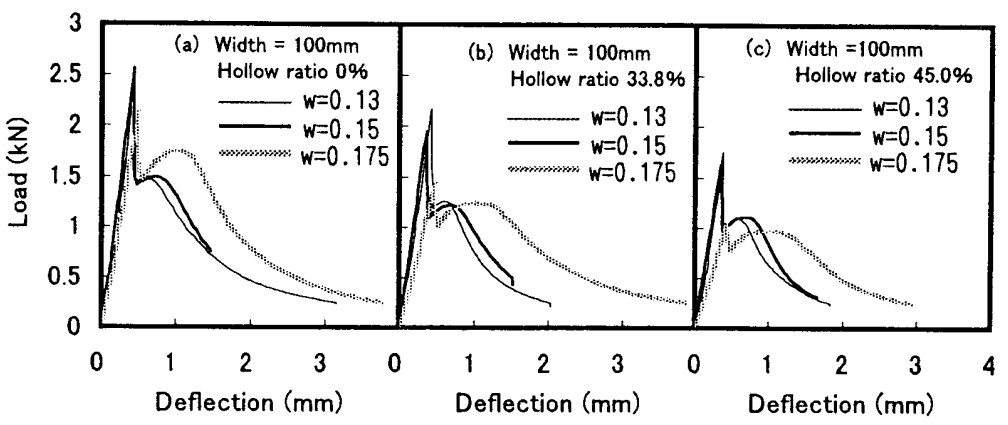

Figure 6 Flexural load - deflection relationships (Polypropylene, width $100 \mathrm{~mm}$, 28days) 
のひび割れ発生曲げ強度の差は大きくなる傾向が認められた。

緎維質添加材として親水性化 PP を用いた部材の結果について、同 図(c)に部材幅 $60 \mathrm{~mm} 、(\mathrm{~d})$ に同 $100 \mathrm{~mm}$ の結果を示す。部材幅 $60 \mathrm{~mm}$ に ついては水量比 0.15 の 1 水準のみであるためこの結果のみですべ ての傾向を論じることはできないが、親水性化 PP を用いた部材の全 体的な傾向として、幅が $60 \mathrm{~mm} 、 100 \mathrm{~mm}$ ともに同一水量比の場合、空 洞化率增大に伴いひび割れ発生曲げ強度は低下し、水量比が大きい ものほど、空洞率の增大に伴って曲げ強度が低下する割合は大きく なる傾向となった。

\subsection{2断面の空洞化による部材の悢密化傾向}

\subsubsection{1 押出成形直後における部材の空気量と水量}

押出成形直後における部材の緻密化傾向を把握するために、 「3.4 有効セメント水比」において述べた手順で部材に残存する空 気量と水量を算出した。Figure 8 の上段に空気量、同図下段に設計 時の水量に対する混練・成形工程において散逸した水量の割合を示 す。同図(a)、(b)は繊維質添加材としてクリソタイルを、同図(c)、

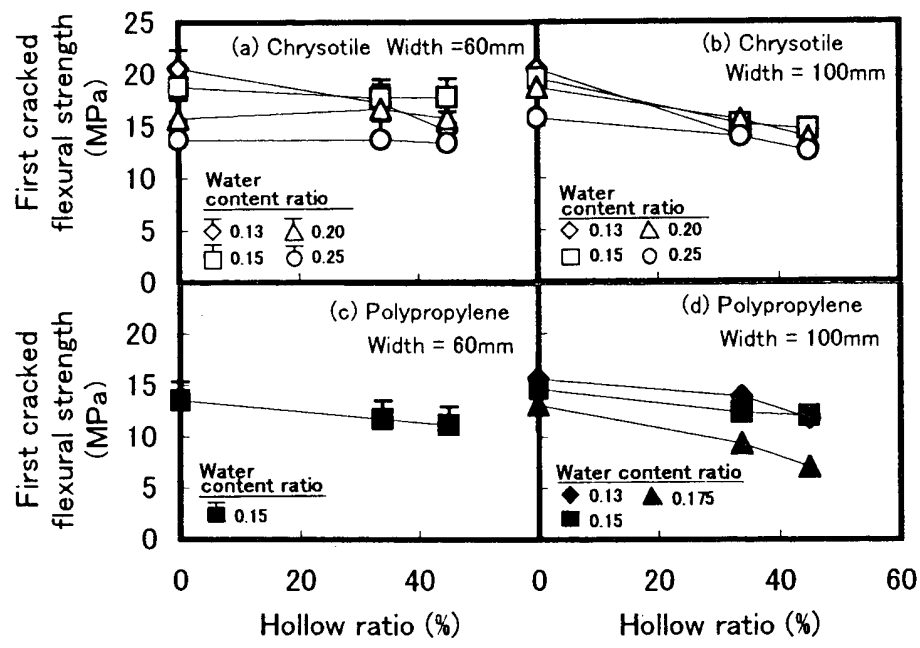

Figure 7 Relationships between first cracked flexural strength and hollow ratio (28days)
(d)は親水性化PP を用いた部材の結果である。なお、同図(a)に示す クリソタイルを用いた部材幅 $60 \mathrm{~mm}$ のシリーズに関して、空洞率 $0 \%$ の水量比 $0.15 、 0.20$ 、および空洞率 $45.0 \%$ の水量比 0.13 については、 各測定值が適切に得られなかったため、図中にはプロットされてい ない。

同図(a)、(b)より、瀻維質添加材としてクリソタイルを用いた部 材において、部材幅 $60 \mathrm{~mm} 、 100 \mathrm{~mm}$ ともに空気の混入が認められたの は空洞率 $0 \%$ の中実断面の部材のみであり、空洞率 $33.8 \%$ 、および $45.0 \%$ にいては部材中に空気はほとんどなかったという結果とな つた。また、この空洞率 $0 \%$ 部材の空気量は、水量比が大きい方が 小さくなる傾向を示すことがわかった。散逸した水の割合について も、空気量と同様に、水量比が大きくなるとともに小さくなる傾向 にあることがわかった。これは、水量比が小さくなると部材を押し 出す際の圧力が上昇し、摩擦により熱が発生し、水が蒸発しやすく なったことによるものと考えられる。また、散逸した水の割合は、 部材の空洞率と反比例の関係となり、空洞率 $0 \%$ の部材が最も大きく なった。この傾向は幅 $60 \mathrm{~mm} 、 100 \mathrm{~mm}$ のいずれの部材ともに共通した。

同図(c)、(d)より、押出成形直後の部材に含まれる空気量は、繊 維質添加材として親水性化 PP を用いた部材の方がクリソタイルを 用いた部材よりも大きくなる傾向にあることがわかる。同図(c)の部 材幅 $60 \mathrm{~mm}$ については、空洞率 $0 \%$ に部材の空気量が非常に小さくな り、クリソタイルの部材とは異なる傾向を示した。クリソタイルを 用いた部材の場合は、全体的に水量比が大きくなるとともに空気量 が小さくなる傾向となったが、同図（d）に示す親水性化PP の結果 を見る限りは、この傾向は明らかではなく、水量比が 0.13 から 0.15 になる段階では空気量は減少しているが、さらに水量比が 0.175 に なると空気量は一転して増大した。また、クリソタイルを用いた空 洞断面部材については、いずれの水量比においても空気量はほぼ $0 \%$ であったが、同図(c)、(d)に示されたとおり親水性化 PP ついては非 00 常に高い割合で部材中に空気が含まれているという結果となった。 散逸した水量については、幅 $60 \mathrm{~mm}$ の部材はほぼ $0 \%$ という結果とな ったが、幅 $100 \mathrm{~mm}$ の部材は水量比が大きくなるほど隇少する傾向に あり、この点については、クリソタイルを用いた部材と同じ傾向で

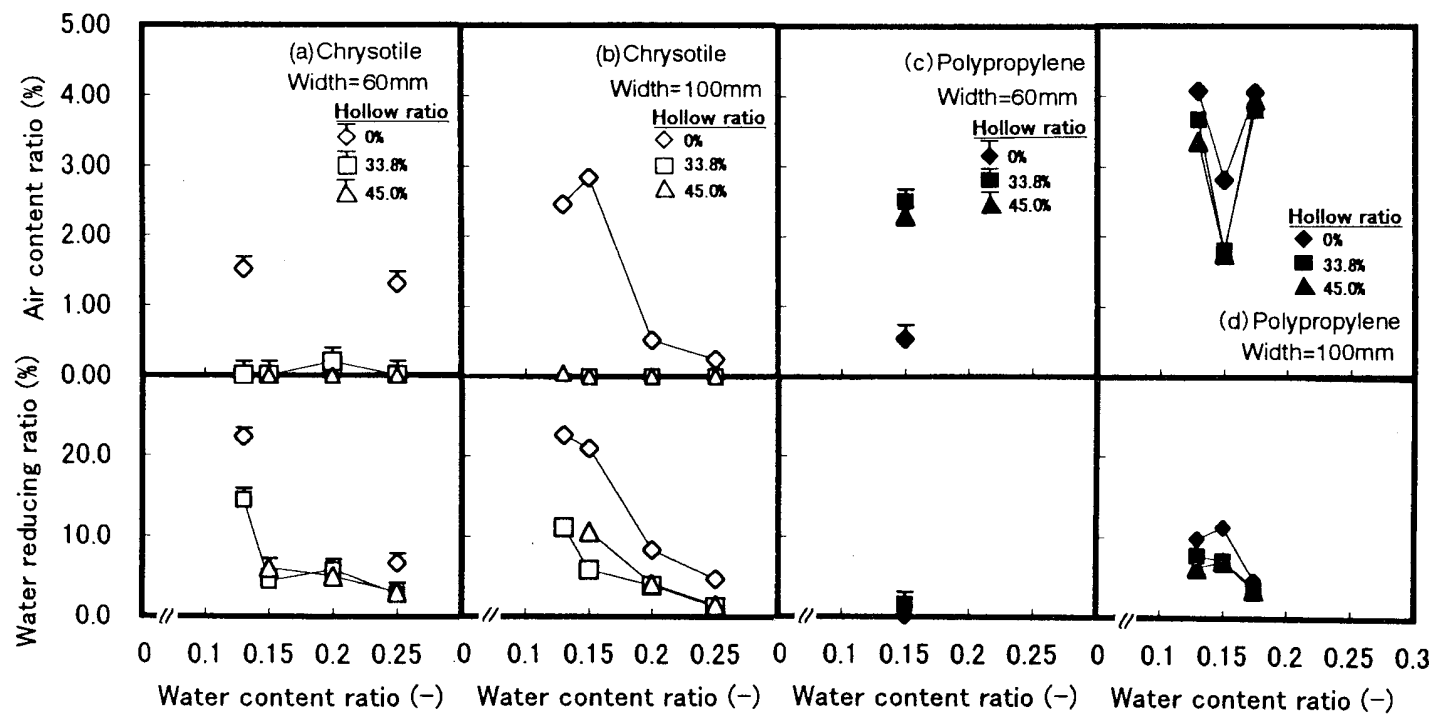

Figure 8 Results of air content ratio and water reducing ratio after extrusion to design 
あった。

以上の結果より、混練・成形工程で散逸する水量や空気の混入量 は断面の空洞率によって違いがあり、散逸する水の割合が大きい中 実断面は混入する空気量も大きく、また散逸する水の割合が小さい 空洞断面は混入する空気はほとんどないということがわかった。

\subsubsection{2 水量比と表乾密度}

Figure 9 に水量比と表乾密度との関係を示す。同図より、いずれ の調合、断面形状においても、水量比が大きくなるとともに表乾密 度が小さくなっている。しかしながら、同図において水量比毎に空 洞率による表乾密度を比較した場合、空洞率が異なっても表乾密度 の值には大きな差は認められず、この図から空洞率による表乾密度 の影響を見出すことはできなかった。

\subsubsection{3 調合設計時と押出直後の水セメント比}

Figure 10 に Talbot のセメント空隙比説 ${ }^{14)}$ に基づいて算出した 有効水セメント比と水量比との関係を示す。なお、同図中の実線は、 調合設計時での水セメント比である。同図(a)より、クリソタイルを 用いた部材は、有効水セメント比が調合設計時のものに比べて小さ くなっており、これは成形工程における散逸する水の割合が大きい ためであると考えられる。同図(b)に親水性化 PP の結果を示すが、 水量比 $0.13 、 0.15$ についてはほぼ設計時の水セメント比と同じであ つたが、水量比 0.175 については散逸する水量の割合に対して混入 する空気量が多くなったため、設計段階の水セメント比よりも有効

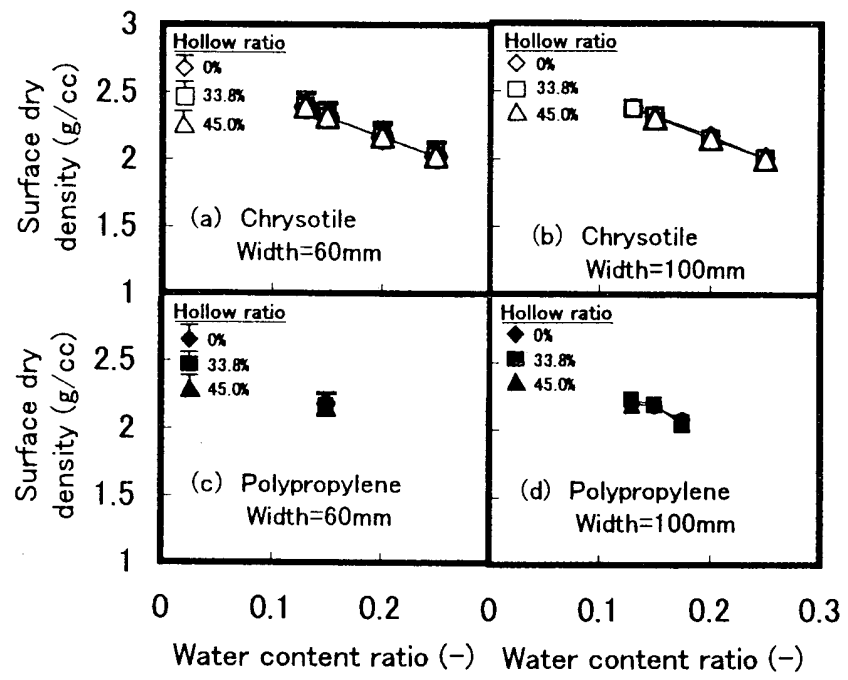

Figure 9 Relationships between water content ratic and surface dry density (after extrusion)

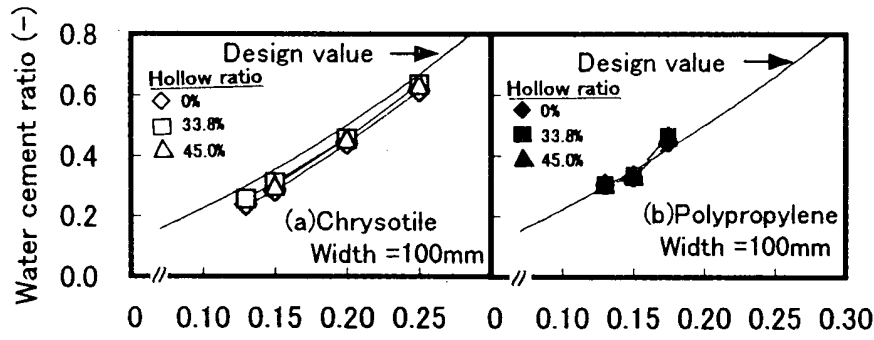

Water content ratio (-) Water content ratio(-)

Figure 10 Effective water cement ratio and design one
水セメント比が大きくなったと考えられる。

これらの結果より、本研究で成形した部材の調合および断面形状 の範囲において、クリソタイルを用いた部材は水量比に関係なく緻 密化されやすいこと、また、親水性化PP を用いた部材は水量比が大 きくなると緻密化されにくい傾向にあることがわかった。なお、前 項同様に、有効水セメント比においても部材断面の空洞化による水 セメント比の差を認めることはできなかった。

\subsubsection{4 践維質添加材とひび割れ発生曲げ強度}

クリソタイルと親水性化 PP を用いた部材のひび割れ発生曲げ強 度を、同一水量比・同一断面形状について比較すると、全体的にク リソタイルの方が強度は大きい。一般的に、ひび割れが発生するま での繊維とマトリックスとが弾性的に挙動する領域では、ひび割れ 発生時の強度は繊維の量や緎䧽の弾性係数の影響を受け、弾性係数 の大きな繊維を用いた部材の方が強度は大きくなるとされているが、 新素材繊維を用いたセメント系押出成形部材の既往の研究"1では、 必ずしもこのような結果とはなっておらず、弾性係数が大きな緎維 を用いても結果として部材が緻密化されず、強度は向上しなかった という結果が出ている。今回用いた親水性化 PP の弾性係数はクリソ タイルに比べて小さいが、Figure8 に示すとおり空気の混入量も大 きく、緻密化の程度も低いという結果出ており、親水性化 PP のひび 割れ発生曲げ強度がクリソタイルを下回った要因としては、絟密化 の程度が大きく影響しているものと考えられる

\subsection{3 有奻セメント水比とひび割れ発生曲げ強度}

\subsubsection{1 有奻セメント水比とひひ制れ発生曲げ強度}

Figure 11 に有効セメント水比とひび割れ発生曲げ強度との関係 を示す。同図(a)は絨維質添加材としてクリソタイルを、同図(b)は 同様に親水性化 PP を用いたものである。

同図(a)より、クリソタイルを用いた部材の幅 $60 \mathrm{~mm}$ および $100 \mathrm{~mm}$ の空洞率 $0 \%$ の部材、高セメント水比領域を除いた幅 $60 \mathrm{~mm}$ の空洞断 面部材、および低セメント水比領域にある幅 $100 \mathrm{~mm}$ の空洞断部材の ひび割れ発生曲げ強度については、有効セメント水比と一つの直線 関係となることが明らかとなった。なお、部材幅 $100 \mathrm{~mm}$ の空洞断面 部材については、セメント水比が大きくなっても、すなわち水量比 が小さくなってもひび割れ発生強度は向上せず、強度発現が困難な 傾向にあり、他とは若干異なる結果となった。

同図(b)より、親水性化 PP を用いた部材については、部材幅には 関係なく、ひび割れ発生曲げ強度は有効セメント水比と直線関係に あることがわかったが、その関係は唯一ではなく、中実部材と断面 空洞部材とではそれそれれ異なっていることがわかった。

\subsubsection{2 ひび割れ発生曲げ強度に及ぼす成形工程の要因}

押出成形では製造機械の特性を考慮せずに工程を進めていくと、 材料調合と機械特性の相互のバランスが崩れ、押し出された部材の 表面には、波打ちやひび割れといった欠陥が生じる。今回の成形し た部材に関しては、外見的にこのような欠陥は镜察されなかった。

しかしながら、幅 $100 \mathrm{~mm}$ の部材を成形するときに材料の押し出し が困難となる状態となった。今回の成形にあたっては材料の押し出 し易さを考虑して実験計画を立てたが、クリソタイルを用いた幅 
$100 \mathrm{~mm}$ の部材を成形する際に給材不足の傾向となり、水量比が最も 小さい 0.13 の部材については、成形途中で材料が閉塞した。この原 因として考えられるのが、材料の給材を調整する「目㘞」であった。

「3.2.2 押出成形工程と成形機械」で記述したとおり、幅 $60 \mathrm{~mm}$ と $100 \mathrm{~mm}$ では使用した成形機は異なり、幅 $100 \mathrm{~mm}$ の部材についてはも ともと成形にセットされていた孔の径が小さいタイプの目皿を使用 した。そのため、水量比が小さい材料の成形時に閉塞したと考えら れる。その後、すぐに径の大きな目皿に交換し、成形を続けること ができた。親水性化 PP の幅 $100 \mathrm{~mm}$ の部材についてはこの後に成形し たので、このような問題は起こらなかった。

Figure11(a)に示したクリソタイルの幅 $100 \mathrm{~mm}$ の空洞断面部材に ついて、ひび割れ発生曲げ強度は有効セメン水比が大きくなっても 横這い、もしくは若干低下するという傾向であったのに対して、同 図(b)の親水性化 PP では有効セメント水比の增大とともにひび割れ 発生曲げ強度は向上するという結果となった。このような差が出た 要因として、成形工程での「目皿」の影響があったものと考えられ る。

\subsubsection{3ひび割れ発生曲げ強度に及ぼすバレル径と部材幅の関保}

フレッシュなモルタル試料は、押出成形のバレル内のスクリュー によって加圧され、塑性加工されながら所定の断面形状の部材にな る。部材幅 $100 \mathrm{~mm}$ についてはバレル径 $75 \mathrm{~mm}$ の押出成形機を、幅 $60 \mathrm{~mm}$ についてはバレル径 $50 \mathrm{~mm}$ のものを使用しており、成形時における材 料の形状の変化、つまりモルタル試料がバレルから部材幅方向に引

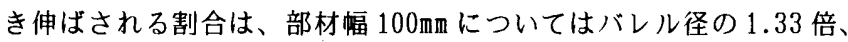
同 $60 \mathrm{~mm}$ についてはバレル径の 1.2 倍である。

Figure11を見る限りでは、ひび割れ発生曲げ強度に及ぼす部材幅、 およびバレル径と部材幅との比の影響は小さいと考えられる。

しかしながら、空洞断面部材で部材の幅が大きくなると、成形機 の目皿等をはじめとする機械特性を適切に管理していなければ、成 形が困難となることが起こり、強度の低下を引き起こすなどの問題

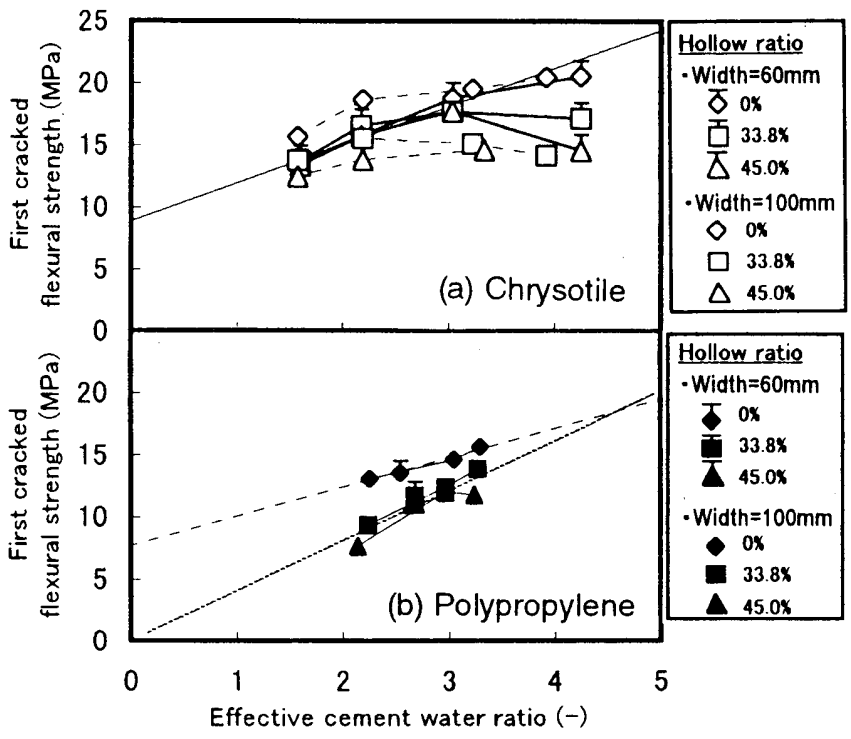

Figure 11 Relationships between first cracked flexural strength and effective cement water ratio (28days)
が発生しやすくなるものと考えられる。

\subsubsection{4 ひび割れ発生曲げ強度の推定}

クリソタイルを用いた部材では、空洞断面部材であっても、ひび 割れ発生曲げ強度は有効セメント水比で概ね予测できることがわか つた。一方、親水性化 PP を用いた部材のひび割れ発生曲げ強度は、 空洞断面部材の方が同一水量比の中実部材の強度よりも小さくなり、 中実部材と空洞断面部材とでそれそれに有効セメント水比とひび割 れ発生曲げ強度との関係が成立するという結果となった。

ポリプロピレン緘維は、弾性係数が基材であるモルタルに比べて 小さいので、ひび割れ発生曲げ強度の向上よりも、ひび割れを分散 させる効果の方が大きいと言われている。今回の部材についても、 小さなひび割れを分散させながら荷重は増大していったと考えられ る。ここで成形した空洞断面部材のフェイスシェル厚さは、空洞率 $45.0 \%$ て $5 \mathrm{~mm}$ 、同 $33.8 \%$ で $6 \mathrm{~mm}$ である。空洞断面ではフェイスシェル が極めて薄いため、微細なひび割れが纎維の位置で捕捉されず、容 易に空洞部まで貫通し、それが部材の挙動を決定的なものとする部 材のひび割れになったと考えられる。

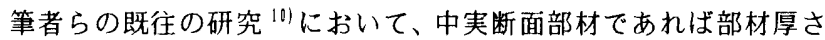

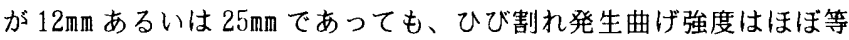
しいと言う結果を得ている。今回の結果のみでは強度低下を起こさ ない部材厚さを推定することはできないが、部材設計をおこなうた めに、今後、この点についての検討が必要と考えられる。

\section{3 換算曲げ強度と曲げ比強度}

纎維質添加材としてクリソタイル、ならびに勒性付与が確認され た親水性化 PP を用いた部材の換算曲げ強度と水量比との関係を Figure 12 に示す。同図(a)は部材幅 $60 \mathrm{~mm} 、(\mathrm{~b})$ は部材幅 $100 \mathrm{~mm}$ にお ける結果である。同図(a)および(b)より、クリソタイルを用いたセ メント系押出成形部材のひび割れ発生曲げ強度は一般のセメシト系 部材と比較して非常に大きい値を示すものの、換算曲げ強度を算定 すると、親水性化 PP のおよそ半分程度と小さく評価されることがわ かる。また親水性化 PP の空洞率 $45.0 \%$ 部材は、水量比が高くなる と換算曲げ強度が低下する傾向を見せるが、全般的に水量比の增大 とともに大きくなる傾向を示した。空洞率の影響については、同一 水量比で比較すると換算曲げ強度は空洞率が大きいほど小さくなり、 この点は、ひび割れ発生曲げ強度の場合と傾向が同じとなった。な お、幅 $60 \mathrm{~mm}$ の空洞断面部材と幅 $100 \mathrm{~mm}$ の部材とを比較すると、僅か ではあるが部材幅が小さい方が換算曲げ強度は大きくなっているが、 これは、「4.1荷重一たわみ曲線」において述べたように、部材幅 $60 \mathrm{~mm}$ の方が $100 \mathrm{~mm}$ よりもひび割れ発生後の変形性能が優れ、変形に 伴う荷重の低下が緩やかであったことによると考えられる。

繊䧽質添加材としてクリソタイルを用いた幅 $60 \mathrm{~mm}$ の部材につい て、水量比 0.13 を除いた部材のひび割れ発生曲げ強度を部材の嵩密 度で除して得られた曲げ比強度をFigure 13 に示す。同図より、空 洞率 $33.8 \%$ の部材にあっては空洞率 $0 \%$ の部材の約 1.5 倍、空洞率

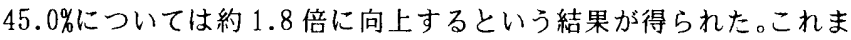
では部材断面の空洞化による曲げ比強度の向上は理論的な検討結果 のみが報告されていたが、本研究において実験的に確認することが できた。 


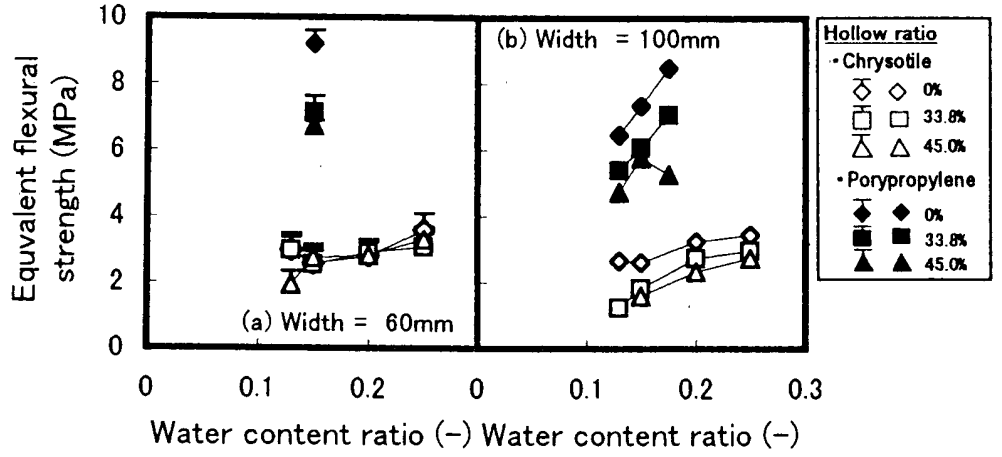

Figure 12 Relationships between equivalent flexural strength and water content ratio (28days)

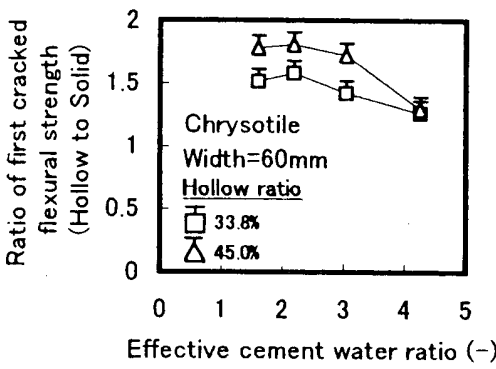

Figure 13 Relationships between effective cement water ratio and flexural strength ratio of hollow to solid (First cracked flexural strength, 28days)

\section{5. まとめ}

セメント系押出成形部材の断面を空洞化することによる曲げ性能 について実験的検討を行った。その結果、以下の点が明らかになっ た。

1 ）㵶維質添加材としてクリソタイルを用いたセメント系押出成 形部材のひび割れ発生曲げ強度は、断面形状に関係なく有効セ メント水比と直線関係になり、強度は有効セメント水比により 予測できる。

2 ）織維質添加材として親水性化ポリプロピレンを用いたセメン 卜系押出成形部材のひび割れ発生曲げ強度は、有効セメント水 比と直線関係となる。しかし、クリソタイルを用いた部材とは 異なり、中実断面部材と空洞断面部材とでそれらの関係は異な る。

3 ）ひび割れ発生強度に及ぼす部材幅の影響は小さい。

4) 勒性付与が確認された親水性化ポリプロピレンを用いると、ク リソタイルを用いた部材に比べて換算曲げ強度は飛躍的に向 上する。また、断面の空洞率が大きくなると換算曲げ強度は小 さくなる。

なお、今後は部材を構成する各種材料のヤング係数等の材料特性 值とひび割れ発生曲げ強度の関係について取りまとめる予定である。

\section{[謝辞]}

本報告は、（社）建築研究振興協会「コストダウン構エ法研究委貝 会 (馬場明生委貝長)」において実施された研究成果の一部を取りま とめたものである。本研究の遂行にあたり、(株) 日本製鋼所 時久 昌吉氏、林 政枝氏、昭和電工橵 松永豊治氏および黒住忠利氏に 協力を頂いた。記して謝意を表す。

\section{[参考文献]}

[1] Mori A., Baba A. and Matsufuji Y. ; An Application of High Strength Extruded Cementitious Materials to Automation Oriented Reinforced Concrete Buildings, Proceedings of the Third International Symposium on NOTEWORTHY APPLICATIONS IN CONCRETE PREFABLICATION, Singapore, pp.111 118, 1992.7

［2] 守明子、馬場明生；セメント系建築材料の押出成形における 製造プロセス制御方法の開発、日本建築学会構造系論文集、 No.456、pp.1 10、1994.2

[3] 守 明子、馬場明生；一面剪断試験によるセメント系建築材料
の押出成形性の評価方法、日本建築学会構造系論文集、No.461、 pp.1 10、1994.7

[4] 守明子、馬場明生 ; 新素材緎維を混入したセメント系材料の 押出成形性、日本建築学会構造系論文集、NNo.484、pp. 1 6、 1996.6

[5]馬場明生、守 明子; セメント系材料の押出成形における成形 圧力を予測するためのダイ開口形状の幾何学的評価方法の提案、 日本建築学会構造系論文集、No.501、pp.1〜6、1997.11

[6] 馬場明生、守 明子、堀口昌利 ; セメント系押出成形部材のプ ロセス制御システムの開発、日本建築学会構造系論文集、No. 513 、 pp.1 8、1998.11

[7]堀口昌利、馬場明生、守 明子、; 押出成形のためのプロセス 制御システムの各種セメント系材料への適用性、日本建築学会 構造系論文集、No.523、pp.1〜8、1999.9

[8] 守明子、馬場明生; 押出成形により製造されるセメント系建 築材料の曲げ強度決定要因、日本建築学会構造系論文集、No.456、 pp.11 19、1994.2

［9］馬場明生、守 明子；新素材緎維を混入したセメント系材料の 押出成形による絰密化と曲げ強度、日本建築学会構造系論文集、 No.486、pp.1〜8、1996.8

[10] 山田寛次、三橋博三；ポリプロピレン短瀻維補強セメント系 押出成形材料の高鞄性化のメカニスムに関する考察、日本建築 学会構造系論文集、No.520、pp.1〜8、1999.6

[11] 眞方山美穂、馬場明生、守 明子、堀口昌利、渡部嗣道 ; 七 メント系押出成形部材の曲げ強度および勒性に及ぼす調合およ び部材厚さに関する実験的研究、日本建築学会構造系論文集、 No.527、pp. 1 8、2000.1

［12］守明子、馬場明生、渡部嗣道; 薄肉打込み型朹材料の工場 生産技術の開発(その3 押出成形部材の断面設計 中空断面) 自動化適合型鉄筋コンクリート構法の開発 (23)、日本建築学会 大会学術講演梗概集、北陸、1992.8

[13] 繊維補強コンクリートの試験方法に関する基準、JCI-SF-4、 日本コンクリート工学協会

[14] Talbot and Richard ; Bull,137, Univ. of Illinois, Engineering Experiment Station, 1923

（2000年 7 月 10 日原稿受理，2000年 12 月 21 日採用決定） 